\title{
Pasientmedvirkning ved beslutninger om behandling
}

\begin{abstract}
Lovverket krever at pasienter medvirker i beslutninger om behandling som gjelder dem selv. Det høres tilforlatelig ut og få vil i dag stille spørsmål ved prinsippet. I realiteten er det en kompleks og tidkrevende prosess som krever veiledet trening, blant annet fordi pasienters behov for medvirkning er både person- og situa-
\end{abstract} sjonsavhengig.

Pål Gulbrandsen

pal.gulbrandsen@medisin.uio.no

Eirik Hugaas Ofstad

Trygve Holmøy

Per Olav Vandvik

Pasientrettighetsloven slår fast at pasienter har rett til å medvirke ved valg mellom tilgjengelige og forsvarlige undersøkelsesog behandlingsmetoder. Videre skal tjenestetilbudet så langt som mulig utformes i samarbeid med pasienten, og det skal legges stor vekt på hva pasienten mener. Det heter videre at pasienten skal ha nødvendig informasjon for å få innsikt i sin helsetilstand og innholdet $i$ helsehjelpen, mulige risikoer og bivirkninger (1). Imidlertid er situasjonene der leger møter pasienter, ytterst ulike, og det er stor forskjell mellom pasienter når det gjelder kunnskapsnivå, helseforståelse, vilje til og interesse for medvirkning. Hvordan kan legen fylle lovens krav? I denne diskusjonen begrenser vi oss til beslutninger om behandling. Beslutninger om valg av undersøkelser, inkludert screeningverktøy, er om mulig enda mer komplisert.

At pasienter, når det er mulig, involveres $i$ beslutninger om behandling, er fundert på et etisk imperativ - respekt for pasientens autonomi (2). Men det var jo ikke slik for et halvt århundre siden. Fremveksten av dagens ideal følger av at befolkningen blir stadig bedre utdannet (3), støttet av iherdig arbeid fra pasientorganisasjoner og en del faglige idealister. Involvering i beslutninger er en vesentlig del av pasientsentrert kommunikasjon, som har vært promotert siden 1970-årene (4, 5). Det meste av forskningen på lege-pasient-kommunikasjon har vært drevet av tilhengere av denne kommunikasjonsmetoden. Som en hovedregel har forskningen vært deskriptiv, men med klare normative innslag. Det har vært få kritiske røster. I 2011 konkluderte imidlertid Pilnick \& Dingwall etter en grundig analyse at den grunnleggende asymmetrien i lege-pasientforholdet består selv etter flere tiår med treningsprogrammer i pasientsentrert kommunikasjon, og at det bør stilles spørsmål ved om metoden er hensiktsmessig (6). En Cochrane-oversiktsartikkel fra 2012 viste at pasientsentrert kommunikasjon gir blandede resultater målt ved pasienttilfredshet, atferd og helse (7). Dette har medført stigende interesse for hvilke detaljer innenfor samlebegrepet pasientsentrert kommunikasjon det er som virker, og hvilke som ikke virker. Blant de områdene som er dårligst belyst, er selve informasjonsutvekslingen og det å ta pasienten med på råd. At pasienter er opptatt av å motta god informasjon, hersker det ikke tvil om $(8-10)$.

\section{Tillitens betydning}

I kollegiale samtaler hører vi stadig at om legen forsøker å ta pasienten med på råd om behandling, blir de ofte vennlig avvist med utsagn som «Er det ikke du som er legen, da?». Eller pasienten vender spørsmålet tilbake til legen: «Hva mener du?» Disse erfaringene tas til inntekt for at det å involvere pasienten ofte ikke fungerer og derfor nærmest er bortkastet tid. En god analyse av dynamikken i disse situasjonene er gjort av den norske filosofen Harald Grimen, i en artikkel om sammenhengen mellom tillit, risiko og makt (11). Grimen hevder at disse tre begrepene står i et uløselig forhold til hverandre i helsetjenesten. Den syke opplever en eller annen grad av risiko og trenger assistanse for å redusere den. Den som kan være i stand til å vurdere risikoen, og forhåpentligvis har makt til å gjøre noe med den, er legen. I denne sårbare situasjonen er tillit til legen nødvendig. Hvis legen i en slik situasjon tar initiativ til at pasienten skal være med på, og til og med selv ta avgjørelsen, kan det både forvirre og skape utrygghet. Fordi denne balansen er så skjør, kreves det både at legen tenker gjennom hvilke beslutninger pasienten bør involveres $\mathrm{i}, \mathrm{og}$ at han håndterer situasjonen nennsomt.

To av forfatterne har inngående kjenn- skap til et materiale bestående av 380 videoer fra Akershus universitetssykehus. I dette materialet finnes det kun en håndfull situasjoner der pasienten på en hensiktsmessig måte involveres i beslutningene. Pasientene blir forsøkt involvert i mange beslutninger uten å bli gitt forutsetninger for det, mens de ofte ikke blir tatt med på råd når de absolutt burde. Disse observasjonene er under publisering, men vi ønsker allerede nå å ta problemstillingen opp i denne kronikken fordi det er et så påtrengende sprik mellom praksis og lovverkets krav, og vi ønsker oppmerksomhet og debatt omkring dette.

Legene skal ikke lastes; opplæring og veiledning har ikke vært tilgjengelig. Det hersker imidlertid en tro på at alminnelig mellommenneskelig samtalekompetanse eller medisinstudienes basisopplæring er tilstrekkelig. Dette er omtrent som å tenke at bare du kan skjære brød, så kan du vite når du skal åpne en abdomen og føre kniven selv.

\section{Ingen medvirkning ved klare retningslinjer?}

Det er i dag ingen internasjonal enighet om hvilke beslutninger pasienten bør involveres i. Mange mener at der det foreligger klare retningslinjer for behandling, det vil si at lovparagrafens begrep «forsvarlig behandlingsmetode» er nedfelt skriftlig, er pasientmedvirkning ikke nødvendig. Denne oppfatningen er imidlertid ikke i tråd med nye standarder for faglige retningslinjer (12).

Manglende pasientmedvirkning blir tydelig eksponert innen kardiologi. Selv ved invasiv hjertemedisin brukes liten tid på pasientmedvirkning (13). Pasienter i denne situasjonen har stor tillit til legens beslutningskompetanse, men opplever likevel at det er godt å bli tatt med på råd (13). Det er vanlig i norske sykehus at pasienter med hjerteinfarkt settes på en rekke medikamenter som skal brukes lenge, noen av dem hele livet, uten at dette gjøres til gjenstand for diskusjon.

Vi vil reise to prinsipielle innvendinger mot en slik praksis. For det første er medi- 
kamenter en aktiv manipulasjon av pasientens kropp som kan ha like store konsekvenser som et kirurgisk inngrep. Er det ikke da naturlig i det minste å informere om hva hvert medikament gjør, og hvordan pasienten vil oppleve at det virker? For det andre, det hører med til sjeldenhetene i medisinen at et medikament har en så ekstrem effekt at en avveining av fordeler mot ulemper ikke er berettiget. Studier har beskrevet at en tredel av pasienter med kardiovaskulære sykdommer nærer stor bekymring for sin medikamentelle behandling (14), og en stor andel avslutter sin behandling innen en måned etter utskrivning etter hjerteinfarkt (15). Kanskje ville bedre medvirkning kunne påvirke dette? Når man skal forskrive seks medikamenter, er det forståelig at det er tid å spare på ikke å gå i detaljer. Men er det riktig å la være?

Nye immunmodulerende medikamenter mot multippel sklerose (MS) illustrerer også viktige prinsipielle spørsmål om grensene for pasientmedvirkning. Generelt ser det ut til at medikamentene som bremser sykdommen mest effektivt, også gir størst risiko for alvorlige bivirkninger (16). Retningslinjer kan ikke alene styre behandlingsvalg når det er slik. Avveining av effekt og risiko er valg som pasienter bør få være med på. Men det finnes også legitime grunner til å begrense pasientens (og legens) rett til å velge fritt. Enkelte medikamenter som brukes ved multippel sklerose, koster for eksempel mer enn 200000 kroner per år, mens alternativene koster under en tredel. Valget har derfor konsekvenser som ikke bare angår pasienten selv. Å snakke med pasienter om samfunnsmessige prioriteringer og personlig risiko under stor usikkerhet er en kommunikativ linedans med stor risiko for å trå feil om legen ikke er godt forberedt og øvet.

\section{Ideal og virkelighet}

Hvis det er slik at beslutninger bare skal diskuteres med pasienten når legen er usikker på hva som er riktig valg, kan det gi utilsiktede effekter. Ved Society for Medical Decision Makings årlige konferanse i Chicago i 2011 ble det retoriske spørsmålet stilt: «Hvorfor er det bare når legen er i alvorlig tvil, at pasientene blir rådspurt?» Pasientene kan oppfatte dette som ansvarsfraskrivning. Legen på sin side kan frykte at en beslutning som ikke gir det ønskede resultatet, skal føre til klage fra pasientens side. Noen av USAs fremste eksperter på kommunikasjon med alvorlig syke, forfatterne av boken Mastering communication with seriously ill patients (17), har utviklet instruksjonsvideoer innen onkologi som ligger på internett (18). I dem ser det ut til at det som anbefales, er at pasienten $m a ̊$ velge, at det bare er et spørsmål om å få gitt tilstrekkelig informa-

Tabell 1 Rekkefølgen av oppgaver i samtalen når pasienter skal involveres i beslutninger. Etter Glyn Elwyn og medarbeidere (22)

Begrunnelse Legen viser at man står overfor et valg, og at det krever oppmerksomhet og diskusjon.

Fellesskap Legen forsikrer pasienten om full støtte i diskusjonen og valgsituasjonen, inkludert at pasienten ikke blir overlatt til seg selv.

Alternativer Legen informerer om fordeler og ulemper ved relevante alternativer.

Preferanser Legen forsøker å få frem pasientens synspunkter, preferanser og prioriteringer nå som informasjonen er på bordet.

Integrering Pasientens preferanser tas med i en samlet vurdering, som også innebærer avklaring av hvem pasienten ønsker skal foreta selve avgjørelsen.

sjon. Hvorvidt dette skyldes sterk vekt på pasientautonomi eller en «ryggen fri»-holdning, skal være usagt.

Forskerne som arbeider mest med involvering av pasienter $\mathrm{i}$ beslutninger, konsentrerer seg om slike vanskelige valg (19-21), og studiene handler vanligvis om å plukke ut én avgjørende beslutning og se nærmere på den. I vårt videomateriale er det i gjennomsnitt godt over ti beslutninger på bordet per lege-pasient-møte, og det sier seg selv at ikke alle kan eller bør tas opp med pasienten. Da ville virksomheten bryte sammen. Det er et gjennomgående inntrykk at legene ikke gjennomfører medvirkningsprosessen slik idealet er beskrevet (tab 1) (22). Noen av de mest tidkrevende passasjene om beslutninger der pasienten involveres, handler om tidspunkt for neste avtale. Da er det kanskje ikke så underlig at noen av de hyppigste årsakene til klager som registreres i helseforetakene og hos pasientombudene, er mangel på informasjon og det ikke å ha blitt hørt.

\section{Hva kan man gjøre?}

Kravene loven stiller, er høye, selv ved en forsiktig tolkning av uttrykk som «medvirke», «så langt som mulig», «legges stor vekt på» og «nødvendig informasjon». Å tilfredsstille lovens krav vil etter vår oppfatning kreve en kulturendring. Det forutsetter en opplæringsinnsats av nasjonalt omfang, og det igjen krever tålmodighet og langsiktighet. Et lovende ledd i dette arbeidet er forslaget om å gjøre kommunikasjonstrening obligatorisk i utdanningen av kliniske spesialister (23). Et annet ledd som kan vise seg nyttig, er utarbeidelsen av internettbaserte beslutningsverktøy som lege og pasient kan bruke sammen, eller som pasienten kan studere hjemme sammen med sine nærmeste (24). Til nå har de hatt begrensninger med hensyn til kunnskapsgrunnlaget de har vært basert på, tilgjengelighet $\mathrm{i}$ praksis og muligheten for å involvere både behandler og pasient $i$ valgene. Faglige retningslinjer har tilsvarende svakheter. Et internasjonalt forskningsog innovasjonsprogram kalt MAGIC (http://www.magicproject.org/share-it/) utvikler derfor en ny generasjon faglige retningslinjer og verktøy som leger og pasienter kan bruke sammen for å dele kunnskap om fordeler og ulemper av behandling. Verktøyene er tilgjengelige på nettbrett. Formålet er å skape gode samtaler. Brukertesting av presentasjonsformatene foregår nå i flere land (25).

En noe mindre avansert, men lett tilgjengelig variant er å finne på $w w w$. optiongrids.org. Helsebiblioteket og Sykehuset Innlandet samarbeider om å utvikle et verktøy som kan bistå ved diskusjon om langtidsbehandling ved bipolar lidelse (Øystein Eiring, personlig meddelelse). Disse verktøyene kan imidlertid ikke i overskuelig fremtid dekke alle mulige kliniske beslutningssituasjoner, og kan også i verste fall føre til en teknologisering av samtalen. Derfor er det nok på sin plass med en viss nøkternhet $\mathrm{i}$ optimismen når det gjelder hva de kan brukes til. Det bør også nevnes at utfordringene vi står overfor, er internasjonale. I en artikkel i JAMA som viser hvordan Kahneman og Tverskys teori om valgpsykologi kan anvendes i krevende kliniske situasjoner, heter det at leger får liten trening $\mathrm{i}$ å forstå hvordan folk fatter beslutninger (26).

Kulturendringen krever mer forskning, formidling, trening, verktøyutvikling og lokale tilpasninger. Forskningen bør dreie seg om optimale måter å få til pasientmedvirkning i beslutninger av ulik art, her er fortsatt mye upløyd mark. De viktigste fallgruvene må formidles ved videre- og etterutdanningskurs i kommunikasjon, og det bør legges til rette for aktiv trening og veiledning på arbeidsplassen. Kunnskapsnivået og veiledningskapasiteten på området må utvikles først; derfor er det urealistisk å regne med rask forbedring av situasjonen. Verktøyutviklingen vil skje både i Norge og internasjonalt. Her i landet bør den drives av relevante fagmiljøer, og trolig koordineres 
av Nasjonalt kunnskapssenter for helsetjenesten.

Lokale tilpasninger vil være nødvendig på grunn av variasjon i organisering og tilgjengelighet av behandlingstilbud. Det er også behov for regelmessig diskusjon mellom fagfolk og brukerrepresentanter om hvilken informasjon som må prioriteres overført til pasientene ved de viktigste beslutningene innenfor hvert fagområde. Dette er kulturarbeid som hvert helseforetak må drive, både for å sikre at informasjonen er relevant i det aktuelle området, og for å holde oppmerksomheten rettet mot pasientmedvirkning som en sentral funksjon i helsetjenesten. En gang i fremtiden vil forhåpentligvis leger knytte sin profesjonelle identitet like sterkt til å beherske denne kunsten som til det å kunne føre en skalpell eller ha oversikt over kunnskapen i sitt fag.

\section{Pål Gulbrandsen (f. 1955)}

er professor i helsetjenesteforskning ved Institutt for klinisk medisin, Universitetet i Oslo, og seniorforsker ved Akershus universitetssykehus.

Forfatter har fylt ut ICMJE-skjemaet og oppgir ingen interessekonflikter.

\section{Eirik Hugaas Ofstad (f. 1978)}

er lege i spesialisering ved medisinsk avdeling, Nordlandssykehuset, Bodø, og doktorgradsstipendiat.

Forfatter har fylt ut ICMJE-skjemaet og oppgir ingen interessekonflikter.

\section{Trygve Holmøy (f. 1960)}

er overlege ved Nevroklinikken ved Akershus universitetssykehus og professor og klinkkleder ved Institutt for klinisk medisin, Universitetet i Oslo.

Forfatter har fylt ut ICMJE-skjemaet og oppgir ingen interessekonflikter.

\section{Per Olav Vandvik (f. 1968)}

er førsteamanuensis ved Avdeling for helseledelse og helseøkonomi, Universitetet i Oslo, forsker ved Nasjonalt kunnskapssenter for helsetjenesten og konstituert overlege ved Sykehuset Innlandet, Gjøvik.

Forfatter har fylt ut ICMJE-skjemaet og oppgir følgende interessekonflikter: Han leder MAGIC som er et forsknings- og innovasjonsprogram og en ideell stiftelse med det formål å utvikle faglige retningslinjer og verktøy for beslutningsstøtte gjennom innovativ teknologi.

\section{Litteratur}

1. Lov om pasient- og brukerrettigheter (pasientog brukerrettighetslovenl.

2. Beauchamp TL, Childress JF. Principles of biomedical ethics. 5. utg. Oxford: Oxford University Press; 2001: 57-112.

3. Coylewright M, Montori V, Ting HH. Patient-centered shared decision-making: a public imperative. Am J Med 2012; 125: 545-7.

4. Stewart M, Brown JB, Weston WW et al. red. Patient-centered medicine. Transforming the clinical method. Thousand Oaks, CA: Sage Publications; 1995.

5. Silverman J, Kurtz S, Draper J. Skills for Communicating with Patients. 3. utg. London: Radcliffe Publishing, 2013.

6. Pilnick A, Dingwall R. On the remarkable persistence of asymmetry in doctor/patient interaction: a critical review. Soc Sci Med 2011; 72: 1374-82.

7. Dwamena F, Holmes-Rovner M, Gaulden CM et al. Interventions for providers to promote a patientcentred approach in clinical consultations. Cochrane Database Syst Rev 2012; 12: CD003267.

8. Coulter A, Jenkinson C. European patients' views on the responsiveness of health systems and healthcare providers. Eur J Public Health 2005 15: 355-60

9. Makoul G, Krupat E, Chang C-H. Measuring patient views of physician communication skills: development and testing of the Communication Assessment Tool. Patient Educ Couns 2007: 67: $333-42$.

10. Skudal KE, Garratt AM, Eriksson B et al. The Nordic Patient Experiences Questionnaire (NORPEQ): cross-national comparison of data quality, internal consistency and validity in four Nordic countries. BMJ Open 2012; 2: e000864.

11. Grimen H. Power, trust, and risk: some reflections on an absent issue. Med Anthropol Q 2009; 23 : $16-33$
12. Vandvik PO, Berg R, Vist G. En ny generasjon troverdige retningslinjer. Norsk Epidemiologi 2013; 23: 197-204

13. Burton D, Blundell $N$, Jones $M$ et al. Shared decision-making in cardiology: do patients want it and do doctors provide it? Patient Educ Couns 2010: 80: 173-9.

14. Viktil KK, Frøyland $H$, Rogvin M et al. Beliefs about medicines among Norwegian outpatients with chronic cardiovascular disease. Eur J Hosp Pharm Sci Pract 2014; 21: 118-20.

15. Ho PM, Spertus JA, Masoudi FA et al. Impact of medication therapy discontinuation on mortality after myocardial infarction. Arch Intern Med 2006 166: $1842-7$

16. Sorensen PS. New management algorithms in multiple sclerosis. Curr Opin Neurol 2014: 27 : 246-59.

17. Gulbrandsen P. Glimrende veiledning til samtaler med alvorlig syke. Tidsskr Nor Legeforen 2012. 132: 1989.

18. http://depts.washington.edu/oncotalk/videos/ (17.2.2014)

19. Makoul G, Clayman ML. An integrative model of shared decision making in medical encounters. Patient Educ Couns 2006; 60: 301 -12

20. Stiggelbout AM, Van der Weijden T, De Wit MPT et al. Shared decision making: really putting patients at the centre of healthcare. BMJ 2012 344 (jan27 1): e256.

21. Elwyn G, Frosch D, Thomson R et al. Shared decision making: a model for clinical practice. J Gen Intern Med 2012; 27: 1361-7.

22. Elwyn G, Tsulukidze M, Edwards A et al. Using a 'talk' model of shared decision making to propose an observation-based measure: Observer OPTION 5 Item. Patient Educ Couns 2013; 93: 265-71.

23. Fremtidens legespesialister. En gjennomgang av legers spesialitetsstruktur og -innhold. Rapport. IS-2079. Oslo: Helsedirektoratet, 2013.

24. Légaré F, Ratté S, Stacey D et al. Interventions for improving the adoption of shared decision making by healthcare professionals. Cochrane Database Syst Rev 2010: nr. 5: CD006732.

25. Vandvik PO, Brandt L, Alonso-Coello P et al. Creating clinical practice guidelines we can trust, use and share: a new era is imminent. Chest 2013; 144: $381-9$.

26. Verma AA, Razak F, Detsky AS. Understanding choice: why physicians should learn prospect theory. JAMA 2014; 311: 571-2.

Mottatt 18.2. 2014, første revisjon innsendt 5.5. 2014 godkjent 2.6. 2014. Redaktør: Hanne Støre Valeur. 